\title{
From author to reviewer to editor: Negotiating the claim in a scientific article
}

A study of French researchers publishing in English

\section{Susan Birch-Bécaas}

\section{OpenEdition}

\section{Journals}

Electronic version

URL: http://journals.openedition.org/asp/3234

DOI: $10.4000 /$ asp.3234

ISSN: 2108-6354

\section{Publisher}

Groupe d'étude et de recherche en anglais de spécialité

\section{Printed version}

Date of publication: 1 December 1997

Number of pages: $397-408$

ISSN: 1246-8185

\section{Electronic reference}

Susan Birch-Bécaas, "From author to reviewer to editor: Negotiating the claim in a scientific article », ASp [Online], 15-18 | 1997, Online since 24 November 2012, connection on 20 April 2019. URL : http:// journals.openedition.org/asp/3234 ; DOI : 10.4000/asp.3234

This text was automatically generated on 20 April 2019

Tous droits réservés 


\title{
From author to reviewer to editor: Negotiating the claim in a scientific article
}

\author{
A study of French researchers publishing in English
}

\author{
Susan Birch-Bécaas
}

1 This study focuses on the problems that French researchers may face when publishing in English. An error analysis of a corpus of first drafts (Birch 1996) has already revealed a number of lexico-grammatical features that non-native speaker (NNS) researchers must master. Here we will analyse the first draft and final version of a research article (RA) written by a French researcher. This will make it possible to identify typical sentencelevel errors that occur in the first draft which are then eliminated by the anglicistcorrector. Then we will focus more closely on the global modifications that may be necessary before the article is accepted for publication, taking into account the cultural differences that may exist between the Anglo-Saxon model and the French RA, the criteria used by reviewers to evaluate articles for publication and the conflict that may exist between the author's claim and what his discourse community will allow him to say. In this way, we will see how the NNS author must be able to produce a version of events which will be acceptable to his readership. He must be able to judge what is known to his readers, what constitutes new and valuable information and what he should regard as being dangerous in that it may contradict the work of his fellow researchers. He must, at the same time though, contribute to the advance of his discipline. Swales has expressed this duality:

The higher the level of claim, the more likely that it will involve contradicting large bodies of the relevant literature and will challenge asumptions embedded in important ongoing research programs. On the other hand, low-level claims may contradict nothing but may also add very little to what is accepted and established within the given research field (1987: 46).

Knowing how to put forward knowledge claims is essential to all scientists and may have important repercussions. Lengthy negotiations with the editor will mean that the paper may not be published for a long time or may even be rejected. Figure 1 (see appendix) 
shows the decisions taken by the journal Thrombosis and Haemostasis. In the first five months of 1995 only $15 \%$ of the articles submitted were accepted, $25 \%$ were rejected outright and $60 \%$ were pending. The time taken by the journal to deal with articles can also be crucial, especially if two teams are working on the same subject. Figure 2 (see appendix) shows the handling time for this particular journal.

\section{Changes at the level of the sentence}

The importance of sentence-level features in the drafting of scientific articles should not be under-estimated. As Gosden (1995: 46) says "it would be simplistic to underplay the influence of L2 proficiency on the extra time, effort and patience required to get NNS researchers' papers published." Although the referees are interested in the content of the paper, they should not be considered as proof-readers. Gosden (1995: 48) points out that grammatical correctness is important "because it can be time-consuming to rectify 'simple syntax problems, poor sentence structure, (and the incorrect) use of definite/ indefinite articles' which accounted for $54 \%$ of language errors most frequently corrected by editors and reviewers." In Gosden's survey, the top four priorities for the editors in question were: a logical and clear linking of sentences; the development of the topic from sentence to sentence in a clear way; grammatically correct sentences and the ability to manipulate the language to make claims.

4 Indeed an error analysis of the article under study reveals persistent errors at the sentence level and in text development which would seem to be common to francophone researchers drafting articles in English. A few examples are given below although they need to be seen in the complete context of the article.

5 The use of the article, especially the zero article, is difficult to master as the researcher must make numerous generic references, describe notions and concepts, refer to chemical compounds and their properties, scientific techniques and procedures.

(1) The 8-azidoadenine was used as a photoaffinity reagent to characterize the purine-cytosine permease of Saccaromyces cerevisiae.

(2) Selective accumulation of solutes inside the cells can be performed by specific systems named permeases incorporated in the plasma membrane.

The use of the tenses is also problematic for the French researcher. When referring to the specific context of the experiment in order to describe his methodology he tends to use the present perfect or the present simple and not the preterit.

(3) After kinetic analysis of the action of the photoaffinity label on the cytosine transport, we have verified that...

We have then measured the amount of polypeptide...

7 The researcher must also distinguish between the simple reporting of results and observations of his experiment in the preterit and the shift to the present to comment upon and highlight certain factors.

(4) It should be pointed out that only half the uptake has been activated whatever the strain studied.

(5) These results obtained in various labelling conditions clearly showed the following i) the plasmid expression in $\mathrm{pAB}$ leads to an overproduction of the $45 \mathrm{kD}$ polypeptide...

8 The French author's statements are not always ungrammatical but they do not always translate his intention and the degree of generality that he wishes to use in each 
statement. This underlines the need for consultation between the corrector and the author who is thus able to explain the impression he would like to convey in such statements.

We also witness problems of textual cohesion, the misuse or lack of relative clauses and coordinating conjunctions to relate utterances.

(6) The gels were cut between wells in lanes. The lanes were sliced.

The expansion of the noun group for reasons of concision and to define and classify by premodification is often not assimilated in the writing of French researchers.

(7) study of the mechanism of this permease has been facilitated by recent data on the nucleotide sequence of the gene of the protein

A further problem is that of the use of prepositions to situate elements in time and space.

(8) the kinetics of cytosine uptake by strains PAB FL442 and pJDB are presented on Figure 1.

12 The lexis which poses problem is of course that of general scientific discourse and not the more specialised terminology.

(9) a permease-less mutant has been used as a control to precise the identity of this polypeptide.

13 These grammatical problems are important as they may irritate the reader, confuse him and in some cases lead to a breakdown in communication. We will now look at the other factors which play a role in the drafting and redrafting of articles.

\section{A model to follow}

14 The theme of the 18th GERAS conference was "Anglais langue de spécialité, français langue de spécialité" and indeed a French researcher publishing in English will need to reorder facts, to present data differently and to develop his argumentation in a different way in English than he would do in French. We have just seen that the francophone author must pay attention to specific grammatical points when drafting an article but the organisation of the data is also important, although this may be more of a problem for doctoral students than fully-fledged researchers.

Several contrastive studies have revealed the non-universal aspects of scientific discourse especially in the way that information and arguments are put forward and Kaplan \& Grabe illustrate this point:

The shaping of a written text by a writer reflects deeply embedded cultural and rhetorical assumptions about what material may be presented, how it is to be organized and how it may be presented in a maximally acceptable way (1991: 200)

Jean-Loup Motchane believes that there are considerable differences in the way of thinking:

La science anglo-saxonne se montrerait souvent plus à l'aise dans l'inattendu, le contradictoire, l'imprévisible, tandis que la science française se distinguerait traditionellement par la rigueur des ses constructions théoriques et par une recherche expérimentale qui s'attacherait moins à découvrir des phénomènes inconnus qu'à illustrer des faits prédits. Ces différences de style se retrouveraient dans les écrits scientifiques, sans, naturellement qu'on puisse en faire une règle. (1990: 46)

Odile Régent (1980: 41) compared a corpus of medical papers in French and English and remarks that "Le paragraphe anglais représente toujours une unité. Il est organisé autour 
d'un argument si le texte est argumenté, il regroupe un certain nombre de données formant une unité si le texte est descriptif; alors que le paragraphe français se présente de manière beaucoup plus fantaisiste et variable." These ideas are reflected in the presentation of the article as the French text is, it seems, lighter, more spaced out and broken up. Elisabeth Crosnier (1995: 177) compared the abstracts and introductions of articles in French and English and it would seem that even beyond the lexis and the grammar the French author must adapt his message to the anglo-saxon model, "les divergences entre les codages des messages scientifiques français et anglo-saxons ne sont pas essentiellement linguistiques." In order to imitate the Anglo-Saxon model, she proposes a possible repetition of words in the title in the first sentence, a rapid move from the general to the specific, a practical concrete tone, the anticipation of contestation and to finish with, a persuasive element.

\section{More global revisions: the criteria of the reviewer}

The next stage after correction by an anglicist is acceptance of the article by the reviewers. Their judgement obviously focuses on the scientific content of the paper and it would seem that the qualities of expression are only considered implicitly: the reviewer demands clarity and precision. The evaluation grids used by the journals focus on criteria such as the pertinence of the study, the length of the article and the different sections, the quality of the figures and the reliability of techniques and statistics. Figure 3 (see appendix) shows the grid for the journal Thrombosis and Haemostasis. We can see that what is important is the adequacy of the content and its potential interest for the readership. The reviewer must judge the presentation of the facts and the length of certain parts of the article but in this way he may indirectly be commenting on the status of the knowledge claim, as Myers says (1985: 616) "criticisms of form - especially length - can sometimes be interpreted as attempts to redefine the claim."

In the case of The British Journal of Haematology (figure 4, appendix) the reviewer must try to establish the level of the author's claim by answering the question "What new observations have been reported in this paper?" and "What is the value of this work as a contribution in its field?" A low-level claim may contribute very little to the field whereas a high-level claim may dangerously contradict the literature of the domain. Indeed, a reviewer may reject a text which he doesn't like or which goes beyond his own research in the field. As Claude Sionis (1995: 99) states the NNS author must constantly bear in mind who he is writing for and adapt his claim to his readers "this lack of situational awareness is often the main reason for the rejection of their articles by reviewers when the texts submitted are globally correct in terms of lexis and syntax." Thus the author will need to revise, reorder data and eliminate any statements that may seem too bold, or on the other hand too vague and imprecise. Latour and Woolgar (1988: 87) describe their activity as follows, "dans un laboratoire, les chercheurs passent leur temps à effectuer des opérations sur les énoncés: ajout de modalités, citation, amélioration, diminution, emprunt, proposition de combinaisons nouvelles". 


\section{Constructing a claim}

20

Jacky Martin has emphasised the importance of the socio-economic parameters in this process. Content will be shaped and constrained and influenced by funding and by the reputations of the researchers. Their job is to expand upon, to verify, to clarify or reject the existing knowledge of the domain. He defines this collective construction of concepts, which are constantly being redefined and broadened by publication as the 'macro-texte'. "Ce texte en tant que pré-construit conditionne et pré-existe à toute production et compréhension des textes scientifiques." The authors and their text are validated once the article has been passed by the referees. The knowledge claims tempered by modals will be viewed against the background of the macro-text and the reader will decide for himself as to their facticity. As Jacky Martin says, the date of writing compared with the date of publication testifies to this period of negotiation between writer and referee and to the accreditation of their findings. Greg Myers expresses this duality:

There is a tension inherent in the publication of any scientific article that makes negotiation between the writer and he potential audience essential. On the one hand, the researcher tries to show that he or she deserves credit for something new, while, on the other, the editors and reviewers try to relate the claim to the body of knowledge produced by the community. (1985: 515)

\section{Final revisions}

Thus, language correction aside, the main types of revision that a NNS author will have to carry out, will be those concerning the strength of his claims and defining the contribution of his paper to the discipline and community. Gosden distinguishes three types of textual revisions:

- addition or suppression of technical data

- reshuffling of statements

- modifications to the rhetoric of the discourse, restructuring new and given information, addition or deletion of hedging devices and statements to reinforce the reasons for and the results of the research.

The majority of the changes are made in the discussion section.

Here, we will study the textual revisions required of a francophone author who is urged to be less vague and imprecise and thus to strengthen his claim if it is to be published. In the examples given, ' $\mathrm{A}$ ' refers to the author's draft and ' $\mathrm{P}$ ' to the published version. We will also quote some of the reviewer's remarks.

First of all, the title is modified to focus on the method and foreground the information.

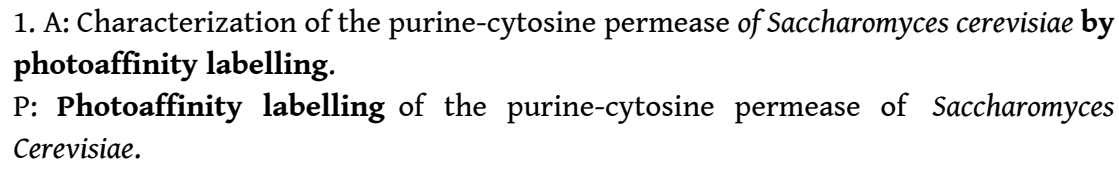

There is a reshuffling of statements in the abstract. The main point of interest in the article needs to be presented as soon as possible to capture the reader's attention. The reviewer comments "Needs reorganisation, certain facts i.e. nitrenes produced by irradiation should be presented sooner so that the results are more relevant to the reader." In both versions the author begins by talking about 8-Azidoadenine but in the 
published version instead of detailing the method, he explains why it was used and its characteristics are given in more general terms. This is indicated by a shift from the preterit to the simple present.

2. A: it was a potent competitive inhibitor of the uptake of cytosine.

$\mathrm{P}:$ it is a potent competitive inhibitor of cytosine uptake.

In the revised abstract, the results are presented much sooner and the information is reshuffled.

3. P: irradiation of the cells incubated with the label induced the irreversible inactivation of cytosine uptake. Addition of excess cytosine prevented this labelling... In the first draft, this information was only given in the second paragraph.

In order to have his article published, the author must attempt to present something new. Thus in the last line of the abstract we see that the hedge is suppressed and the author makes a stronger claim.

4. A: This polypeptide was probably the purine-cytosine permease.

$\mathrm{P}$ : Therefore this polypeptide corresponds to the purine-cytosine permease.

5. A: We noted that the polypeptide chain which was covalently and specifically modified by the labelling agent displayed an apparent molecular weight of about $45 \mathrm{kDA}$

$\mathrm{P}$ : We have provided evidence for one main polypeptide chain with an apparent molecular mass of 45kDA.

The hedge may have been used in the original version to conform to the established writing style or as a politeness strategy (Banks) or it may be a case of "scientific honesty" if the data do not permit a stronger statement (Salager-Meyer).

However, the author's statements must not be too categorical and in the introduction we see that the author is more cautious and opts for a more neutral expression.

6. A: We report improvement of a photoaffinity labelling procedure...

$\mathrm{P}$ : We describe conditions allowing covalent specific photoaffinity labelling.

In Material and Methods, the author has to add more technical data about the experiment but the majority of the changes are found in the discussion. The reviewer considers that there is " too much handwaving - needs a fact or very strong inference" so the researcher reinforces his assertions and reduces the hedging to make a stronger claim.

7. A: The two peptides 45 and $50 \mathrm{kDa}$ are probably related to the permease system (two products of the same gene), since they are not detected for pJDB.

$\mathrm{P}$ : These two polypeptides are clearly related to the permease since they were not detected in the permease-null pJDB 207 strain, and since they were not labelled in the presence of permaease ligand.

In the original version the author launches into a hypothetical explanation but in the published version he has to recognise that the data do not permit him to attempt an explanation.

8. A: What is not clear from the results is the relationship between these two polypeptides. A tentative explanation of this behaviour may lie in the secretory pathway the proteins have to follow to be integrated in the plasma membranes. Overproduction of mRNA could lead to overproduction of the $45 \mathrm{kDA}$ gene product which then might not be fully mature into a $50 \mathrm{kDA}$ glycoprotein

$\mathrm{P}$ : What is not clear from these results is the relationship between the two peptides. At this stage of our studies, no clear explanation can be offered.

He does however add a way forward. 
9. P: Purification and solubilisation (...) should allow better characterization of these entities. These two approaches are currently underway in the laboratory. and adds hedges to modify his original proposition.

10. A: The observed difference between the apparent molecular weight obtained by SDS-Page $(45 \mathrm{kDa})$ and the molecular weight predicted from the sequence of the DNA segment encoding for the FCY2 protein (58kDa) can be easily explained if one considers the well-known influence of SDS concentrations on such determinations. P: The observed difference between the apparent molecular mass obtained by SDSPage $(45 \mathrm{kDa})$ and the molecular mass predicted from the sequence of the DNA segment encoding for the FCY2 protein $(58 \mathrm{kDa})$ might reflect post-traductional maturation of the gene product. However, as previously mentioned, proteolysis during membrane preparation cannot be fully excluded and the influence of SDS on molecular mass determination of integral membrane proteins should be considered.

We have thus seen the differences which exist between the author's version of events and that desired by the editors and reviewers. Certain facts are reinforced, others weakened and all this is done bearing in mind the potential audience. As Greg Myers says:

The same claim may be considered 'speculative' or 'well-defined' a 'highly significant' advance or a 'well-known' observation, depending on the body of literature into which it is placed and the audience which it is read to. (1985: 596)

These modifications to the rhetoric and scientific content cannot be carried out by the anglicist corrector but only by the author himself who knows his readers, the risks he is taking and only he can gauge how certain claims will be received. However, the role of the corrector might be to draw the author's attention to possible dangers. It is essential though to increase the autonomy of francophone researchers in the drafting of articles. Linguistically the author must be able to structure his discourse in such a way that he is able to thematise, emphasise certain concepts and modulate his assertions using or eliminating modal auxiliaries and other forms of hedges such as lexical verbs, adverbs and approximators. Attention should be paid to this relational aspect of the discourse through which the author attempts to gain the support of the community and to convince his peers of the facticity of his results.

\section{BIBLIOGRAPHY}

Banks, D. 1993. "Hedges and how to trim them. In Applications and Implications of Current LSP Research, Proceedings of the 9th European LSP Symposium. Bergen, Norway, 587-592.

Birch, S. 1996. "Les besoins linguistiques des chercheurs français publiant en anglais: Analyse d'un corpus de premières rédactions et de leur correction". Unpublished PhD dissertation, supervised by Michel Perrin, Université Bordeaux 2.

Crosnier, E. 1995. "Les scientifiques français et la publication en langue anglaise: contraintes, obstacles, et perspectives de solutions d'aide à la rédaction. Etude contrastive de corpus anglaisfrançais informatisé d'informatique, de mathématiques, et de mécanique.(Titres, abstracts et 
introductions)". Unpublished PhD dissertation, supervised by Jean-Pierre Soula, Université de Toulouse le Mirail.

Gosden, H. 1995. "Success in RA writing and revision: A social constructionist perspective"? English for Specific Purposes 14/1, 37-57.

Kaplan, R. and W. Grabe. 1991. "The fiction in science writing”. In Subject-orientated texts. Languages for Special Purposes and Text Theory. Berlin: Walter de Gruyter, 200-215.

Latour, B. \& S. Woolgar. 1988. La vie de laboratoire. La production des faits scientifiques. Paris: Éditions de la Découverte.

Martin, J. Linguistique du discours scientifique, Cours non publié du DEA de Langue de spécialité. Bordeaux.

Motchane, J.-L. 1990. “Chercher, inventer, innover dans sa langue”. InCassen, B (ed.), Quelles langues pour la science? Paris: Éditions de la Découverte, 41-62.

Myers, G. 1985. “Text as knowledge claims: The social construction of two biology articles". Social Studies of Science 15, 593-630.

Régent, O. 1980. "Le discours médical écrit en français et en anglais. Étude comparative en vue d'applications pédagogiques".Unpublished PhD dissertation, Université Nancy 2, 1980.

Salager-Meyer, F. 1995. "I think that perhaps you should: A study of hedges in written scientific discourse". TESOL France Journal "Functional Approaches to Written Text. Classroom Applications", 127-143.

Sionis, C. 1995. "Communication strategies in the writing of scientific research articles by nonnative users of English". English for Specific Purposes 14/2, 99-132.

Swales, J. 1987. "Utilizing the literatures in teaching the research paper". TESOL Quarterly 21/1, 41-67.

\section{ABSTRACTS}

This paper deals with the different stages in the process of publication that French researchers must pass through. After a brief discussion of sentence-level revisions, we focus on the more global textual modifications that may be requested by reviewer and editor and the ensuing "negotiations" between author and editor.

Cette étude porte sur les problèmes auxquels les chercheurs francophones doivent faire face lors de la rédaction en langue anglaise. Nous visons à démontrer les difficultés que l'anglais suscite en tant que langue de publication et langue de culture. Ainsi, nous étudions les réactions des reviewers face aux articles de non-anglophones: leurs critères, conseils et les exigences éditoriales, afin de nous pencher sur le processus de négociation entre l'auteur et le comité de rédaction lors des dernières révisions.

\section{INDEX}

Mots-clés: chercheur, reviewer, révision de manuscrits

Keywords: researcher, reviewer, text editing 


\section{AUTHOR}

\section{SUSAN BIRCH-BÉCAAS}

Susan Birch-Bécaas enseigne principalement dans les filières d'odontologie et de médecine au DLVP-CRIFEL à l'Université Victor Ségalen, Bordeaux 2. susan.birch@lv.u-bordeaux2.fr 